\title{
Cost Sensitive Tree dan Nä̈ve Bayes Pada Klasifikasi Multiclass
}

\author{
M. Aldiki Febriantono', Ridho Herasmara ${ }^{2}$, Gusti Pangestu ${ }^{3}$ \\ ${ }^{1,3}$ Computer Science, Fakultas Computer Science, Universitas Bina Nusantara \\ ${ }^{2}$ Teknik Elektro, Fakultas Saintek, Universitas Islam Raden Rahmat \\ ${ }^{1}$ m.aldiki@binus.ac.id, ${ }^{2}$ ridho.herasmara@uniramalang.ac.id, ${ }^{3}$ Gusti.pangestu@binus.ac.id
}

\begin{abstract}
Abstrak
Data mining merupakan proses pengolahan data untuk mengambil keputusan secara cepat, tepat dan akurat. Data mining pada bidang kesehatan dan manufacturing menjadi hal yang sangat penting dikarenakan suatu kesalahan klasifikasi (misclassification) akan memiliki dampak serius. Masalah utama pada data mining ketika data yang digunakan bersifat imbalanced multiclass karena classifier kesulitan untuk mengklasifikasikan data sehingga menyebabkan terjadinya misclassification. Solusi untuk meminimalkan missclasification dengan menggunakan metode cost sensitive pada classifier decision tree C5.0 dan nä̈ve bayes. Penelitian ini menggunakan dataset glass, lympografi, vehicle, thyroid dan wine yang diperoleh dari UCI Respository. Kelima dataset dilakukan proses seleksi atribut menggunakan particle swarm optimazation. Kemudian dataset diuji menggunakan metode cost sensitive decision tree C5.0 dan cost sensitive nä̈ve bayes. Hasil pengujian menggunakan metode cost sensitive decision tree C5.0 diperoleh nilai accuracy pada dataset glass, lympografi, vehicle, thyroid dan wine berturut-turut sebesar $76.17 \%, 83.33 \%, 75.27 \%, 95.81 \%$ dan $95.83 \%$. Sedangkan metode cost sensitive naïve bayes memiliki performa accuracy pada dataset berturut-turut sebesar $32.24 \%, 82.61 \%, 25.53 \%, 97.67 \%$ dan 94.94\%.
\end{abstract}

Kata kunci : cost sensitive, decision tree, multiclass classification, nä̈ve bayes.

\section{Pendahuluan}

Larose (2005), menyatakan Data mining merupakan proses penggalian data atau pencarian pola dengan tujuan mendapatkan informasi sebagai pengetahuan untuk mengambil keputusan secara cepat, tepat dan akurat di waktu yang akan datang. Kemampuan mengambil keputusan secara cepat, tepat dan akurat pada bidang kesehatan dan manufacturing menjadi hal yang sangat penting. Kesalahan mengambil keputusan pada bidang kesehatan dapat berakibat fatal pada kehidupan pasien sedangkan kesalahan pada bidang manufacturing berdampak pada hasil produksi maka dari itu perlu adanya data mining. Pola data dapat dipelajari sebagai dasar pengambilan keputusan. Patel, et. Al. (2012), menyatakan salah satu cara untuk mencari pola data adalah dengan menggunakan teknik klasifikasi. Teknik tersebut menggunakan nilai fitur dari data masukan (atribut) dengan tujuan mengenali pola berupa prediksi class. Menurut Ali, et. al. (2019), berdasarkan hasil prediksinya, klasifikasi dibagi menjadi dua, yaitu klasifikasi binary class, dan klasifikasi multiclass.

Machine learning merupakan bagian dari data mining untuk membantu mencari pola data secara otomatis. Bernard \& Adam (2015) menyatakan pendistribusian data yang tidak sama (imbalanced data) menjadi masalah karena machine learning lebih fokus pada class yang dominan (mayority) dibandingkan dengan class yang sedikit (minority) dikarenakan minority class memiliki jumlah data pelatihan dan pengujian yang lebih sedikit dari pada mayority class. Padahal minority class dapat memiliki pengaruh yang jauh lebih besar jika terjadi salah klasifikasi (misclassification), berdasarkan Wang \& Yao (2012). Pada kasus terjadinya salah klasifikasi sebuah kanker ganas sebagai kanker jinak, dapat berpengaruh sangat buruk bagi Kesehatan pasien, dibandingkan ketika terjadi kesalahan klasifikasi kanker jinak sebagai kanker ganas. Beberapa metode data mining yang digunakan untuk menyelesaikan permasalahan pada data imbalanced adalah decision tree dan naïve bayes.

Konsep decision tree adalah merubah data tabel menjadi model pohon kemudian menghasilkan aturan keputusan (rule), menurut Jauhari \& Supianto (2019). Decision tree memerlukan algoritma untuk membuat model pohon keputusan diantaranya ID3, C4.5 dan C5.0. Algoritma C5.0 memiliki berbagai kelebihan dibandingkan dengan ID3 dan C4.5 diantaranya memiliki waktu komputasi yang cepat, mampu menangani data continue, categorical dan missing value, berdasarkan Patel \& Rana (2014). Mirip dengan decision tree, nä̈ve bayes juga memiliki beberapa kelebihan seperti mudah digunakan, waktu komputasi yang cepat, mampu menanggani missing value dan data continue (Faisal \& Mofizur, 2011). Pendekatan-pendekatan ini lebih baik ketika dibandingkan pendekatan neural network yang menurut Herasmara, et. al (2019), 
membutuhkan waktu dan sumberdaya komputasi yang tinggi karena desain yang cenderung tidak efisien.

Chai, et. Al (2014) berargumen bahwa Cost sensitive learning merupakan metode yang digunakan untuk meningkatkan performa classifier dengan meminimalkan misclassification cost. Pemilihan atribut data juga memiliki peranan yang penting untuk mendapatkan performa yang maksimal. Menurut Wei, et. al. (2008), Particle swarm optimization merupakan algoritma yang digunakan untuk menyeleksi atribut berdasarkan nilai bobot dari setiap atribut.

Haldankar (2016) menuturkan beberapa metode yang telah dikembangkan pada beberapa penelitian dengan menggunakan cost sensitive classifier, diantaranya adalah cost sensitive using random forest dan selection boruta pada data imbalanced nasabah bank. Hasil accuracy dengan menggunakan metode tersebut sebesar $76 \%$.

Penelitian lainnya oleh Daraei (2017), menggunakan metode cost sensitive decision tree C4.5 dan selection genetic algorithm pada data pasien jantung. Hasil accuracy dari metode tersebut sebesar $82.67 \%$. Penelitian lainnya oleh Xiangju, et. al. (2015) menggunakan metode cost sensitive decision tree C4.5 using probabilistic mechanism pada delapan dataset imbalanced. Metode tersebut mampu meminimalkan cost sebesar $10 \%$ pada semua dataset.

Penelitian ini bertujuan untuk membandingan performa metode cost sensitive decision tree C5.0 dan cost sensitive naïve bayes sebagai solusi untuk mengambil keputusan secara cepat, tepat dan akurat pada klasifikasi data imbalanced multiclass. Performa classifer diukur menggunakan parameter accuracy, recall, precision, f-measure dan total cost.

\section{Pendekatan Dalam Data Mining}

\section{A. Data Mining}

Larose (2005) menyatakan bahwa data mining merupakan proses penggalian data atau pencarian pola dengan tujuan mendapatkan informasi sebagai pengetahuan untuk mengambil keputusan secara cepat, tepat dan akurat di waktu yang akan datang Data mining memiliki beberapa teknik untuk mengenali pola antara lain deskripsi, estimasi, prediksi, klasifikasi, clustering dan asosiasi. Patel, et. al. (2012) menyatakan klasifikasi merupakan proses untuk memprediksi class berdasarkan atribut data ke dalam label class yang telah didefinisikan sebelumnya. Zhang, et. al. (2010) menjabarkan tahapan yang dilakukan pada proses data mining adalah pembersihan data (data cleaning), seleksi data (data selection), transformasi data (data transformation), proses data mining, seleksi atribut (atribut selection) dan evaluasi pola (pattern evaluation)

\section{B. Particle Swarm Optimazation}

Pemilihan atribut menjadi faktor penting untuk mendapatkan data yang berkualitas pada proses data mining, berdasarkan Xue, et. al. (2013). Atribut yang tidak relevan dapat dihilangkan sehingga dapat menghasilkan sebuah informasi yang tepat dan akurat. Salah satu algoritma yang digunakan untuk menyeleksi atribut adalah particle swarm optimization (PSO).

PSO merupakan sebuah teknik optimasi untuk menyeleksi atribut berdasarkan nilai bobot atribut (w). Atribut yang relevan memiliki nilai bobot 1, atribut yang tidak relevan bernilai 0 , sementara atribut yang memiliki relevansi parsial akan memiliki nilai bobot atribut pada rentang $0<\mathrm{w}$ $<$ 1. Kelebihan PSO adalah mempunyai konsep sederhana, mudah diimplementasikan, dan efisien dalam perhitungan jika dibandingkan dengan teknik seleksi atribut lainnya. Wei, et. al. (2008) memaparkan dua parameter yang digunakan untuk menentukan bobot atribut yaitu kecepatan dan posisi. Persamaan untuk menetukan kecepatan atribut $i$ pada $d$ dimensi ini ditunjukkan dalam Persamaan 1.

$V_{i d}^{k+1}=w \times V_{i d}^{k}+c 1 \times r 1 \times\left(P_{i d}-X_{i d}\right)+c 2 \times r 2 \times\left(G_{i d}-X_{i d}\right)$

Persamaan untuk menentukan posisi atribut $i$ pada $d$ dimensi ditunjukkan dalam Persamaan 2 .

$$
X_{i d}^{k+1}=X_{i d}^{k}+V_{i d}^{k+1}
$$

$$
\begin{aligned}
& \text { Keterangan: } \\
& V_{i d=} \text { Kecepatan individu ke } i \text { pada } d \text { dimensi } \\
& X_{i d}=\text { Posisi individu } i \text { pada } d \text { dimensi } \\
& \omega=\text { Parameter inertia weight } \\
& c_{1} c_{:}=\text {Learning rate, nilainya antara } 0 \text { dan } 1 \\
& r_{1,2}=\text { Paraeter random antara } 0 \text { dan } 1 \\
& P_{i d}=\text { Pbest (local best) individu } i \text { pada } d \\
& \\
& G_{i d}=\text { dimensi }
\end{aligned}
$$

\section{Algoritma C5.0}

Algoritma C5.0 digunakan untuk membuat pola pohon keputusan (decision tree) berdasarkan nilai entropy dan information gain. Thomas \& Joy (2006) memaparkan tentang Entropy (S) sebagai jumlah bit yang dibutuhkan untuk dapat mengekstrak suatu class dari jumlah data acak pada ruang sample S. Entropy biasa digunakan sebagai suatu parameter untuk mengukur heterogenitas (keberagaman) dari suatu kumpulan sampel data. Jika kumpulan sampel data semakin heterogen, maka semakin besar nilai entropy dan nilai gain semakin kecil. Secara matematis entropy dirumuskan dalam Persamaan 3. 


$$
H(S)=\sum_{i=1}^{n}-p\left(s_{i}\right) \log _{2}\left(p\left(s_{i}\right)\right)
$$

Setelah mendapatkan nilai entropy selanjutnya mencari nilai information gain berdasarkan Pandya \& Pandya (2015). Information gain digunakan untuk mengukur efektivitas karakteristik atribut dalam mengklasifikasikan class. Persamaan 4 digunakan untuk menghitung information gain sebagai berikut.

$$
I G\left(S, A_{i}\right)=H(S)-\sum_{\alpha \in A_{i}}^{n} \frac{\left|S_{\alpha}\right|}{|S|} H\left(S_{\alpha}\right)
$$

Keterangan:

$$
\begin{array}{ll}
\mathrm{H} & =\text { Entropy } \\
\mathrm{S} & =\text { Himpunan kasus } \\
\mathrm{A} & =\text { Atribut } \\
\mathrm{N} & =\text { Jumlah partisi atribut } \mathrm{A} \\
\left|S_{\alpha}\right| & =\text { Jumlah kasus pada partisi ke-i } \\
|S| & =\text { Jumlah kasus dalam } \mathrm{S} \\
\mathrm{p}_{\mathrm{i}} & =\text { Proporsi dari } \mathrm{S}_{\mathrm{i}} \text { terhadap } \mathrm{S}
\end{array}
$$

\section{Metacost}

Metacost merupakan algoritma dari metode cost sensitive learning dengan menggunakan teknik thresholding meta learning untuk meminimalkan cost. Prisip kerja dari metacost adalah menghitung probabilitas setiap class $j$ pada label class $\left(\mathrm{S}_{\mathrm{j}}\right)$ dari model decision tree $\left(\mathrm{M}_{\mathrm{i}}\right)$. Persamaan untuk menghitung probabilitas ditunjukkan pada Persamaan 5.

$$
P(j \mid x)=\frac{1}{\sum_{i} 1} \sum_{i} P\left(j \mid x, M_{i}\right)
$$

Cost dinotasikan sebagai $\left.\mathrm{C}_{\mathrm{i}, \mathrm{j}}\right)$, dimana $i$ adalah aktual class tetapi diprediksi menjadi class $j$ sehingga menyebabkan misclassification. Ketika probabilitas pada label class $P\left(j \mid x, M_{i}\right)>1$, maka akan dilakukan evaluasi dengan cara melakukan teknik pruning dan relabeling sampai mendapatkan minimum cost. Persamaan untuk mencari nilai minimum cost berdasarkan Domingos (1999) ditunjukkan pada Persamaan 6.

$$
S_{i}=\arg \min _{i} \sum_{j} P(j \mid x) C(i, j)
$$

\section{E. Nä̈ve Bayes}

Janasthar \& Hanskunatai (2014) memaparkan Naive Bayes sebagai metode klasifikasi yang mengunakan teorema Bayes dengan mengansumsikan atribut secara independen atau tidak saling ketergantungan. Teorema bayes bekerja dengan memperbaiki atau mengevaluasi probabilitas awal (prior probability) menjadi probabilitas baru (posterior probability) sesuai pemaparan Friedman, Geiger, \& Goldezmidt (1997). Faisal \& Mofizur (2011) sendiri menyatakan bahwa keuntungan penggunaan Naive Bayes adalah bahwa metode ini hanya membutuhkan jumlah data pelatihan (training data) yang kecil untuk menentukan estimasi paremeter yang diperlukan dalam proses pengklasifikasian. Persamaan umum dari Nä̈ve Bayes ditunjukkan pada Persamaan 7.

$$
\mathrm{P}\left(C_{i} \mid A_{i j}\right)=\frac{\mathrm{P}\left(C_{i}\right) \mathrm{P}\left(A_{i j} \mid C_{i}\right)}{\mathrm{P}\left(A_{i j}\right)}
$$

Keterangan:

$\mathrm{C}_{\mathrm{i}}=$ Data dengan class yang belum diketahui

$\mathrm{A}_{\mathrm{ij}}=$ Hipotesis data merupakan suatu class tertentu

$\mathrm{P}\left(\mathrm{C}_{\mathrm{i}} \mid \mathrm{A}_{\mathrm{ij}}\right)=$ Probabilitas hipotesis $\mathrm{C}_{\mathrm{i}}$ berdasar kondisi $\mathrm{A}_{\mathrm{ij}}$ (posteriori probabilitas)

$\mathrm{P}\left(C_{i}\right)=$ Probabilitas hipotesis $\mathrm{C}_{\mathrm{i}}$ (prior probabilitas)

$\mathrm{P}\left(\mathrm{A}_{\mathrm{ij}} \mid \mathrm{C}_{\mathrm{i}}\right)=$ Probabilitas $\mathrm{A}_{\mathrm{ij}}$ berdasarkan kondisi pada hipotesis $C_{i}$

$\mathrm{P}\left(\mathrm{A}_{\mathrm{ij}}\right) \quad=$ Probabilitas $\mathrm{A}_{\mathrm{ij}}$

\section{F. Cost sensitine Nä̈ve bayes}

Chai, et. al. (2004) memaparkan Cost sensitive learning sebagai metode yang digunakan untuk meminimalkan misclassification cost atau kesalahan klasifikasi pada model classifier. Cost function merupakan nilai kesalahan dalam klasifikasi class. Cost function dinotasikan $\mathrm{C}_{\mathrm{i}, \mathrm{j}}$ ) dimana aktual class $i$ diklasifikasikan menjadi class $j$. Pada nä̈ve bayes, misclassification cost disebut juga conditional risk $R\left(c_{j} \mid x\right)$ yang dinyatakan dalam Persamaan 8.

$$
R\left(c_{j} \mid x\right)=\sum_{i} C_{i j} x P\left(c_{i} \mid x\right)
$$

Dimana $P\left(c_{i} \mid x\right)$ adalah probabilitas posterior pada classifier naïve bayes. Untuk mendapatkan minimal conditional risk, digunakan Persamaan 9.

$$
R\left(c_{j} \mid x\right)=\min _{j} R\left(c_{j} \mid x\right)
$$

\section{Klasifikasi Dengan Pendekatan Cost Sensitive}

Penelitian ini memerlukan alat pengujian antara lain microsoft excel 2013 digunakan untuk mengolah data klasifikasi, rapid miner versi 5.3.0 digunakan untuk merancang sistem klasifikasi sedangkan untuk validasi hasil klasifikasi menggunakan MATLAB 2017. 
Dataset pengujian berasal dari University of California Irvine (UCI) machine learning repository dengan url http://archive.ics.uci.edu/ml. Dataset yang digunakan dalam penelitian ini terdiri atas data klasifikasi multiclass. Deskripsi dataset yang digunakan, ditunjukkan pada Tabel 1.

Tabel 1. Deskripsi Dataset Penelitian

\begin{tabular}{llccc}
\hline No & Dataset & $\begin{array}{c}\text { Jumlah } \\
\text { Instances }\end{array}$ & $\begin{array}{c}\text { Jumlah } \\
\text { Atribut }\end{array}$ & $\begin{array}{c}\text { Jumlah } \\
\text { Class }\end{array}$ \\
\hline 1 & Glass & 214 & 10 & 6 \\
2 & Lympografi & 148 & 18 & 4 \\
3 & Vehicle & 946 & 18 & 4 \\
4 & Thyroid & 215 & 5 & 3 \\
5 & Wine & 178 & 13 & 3 \\
\hline
\end{tabular}

Dataset Glass adalah kumpulan data terkait klasifikasi glass (kaca) memilki data jenis real. Dataset Lympografi adalah Data yang memanfaatkan teknologi $\mathrm{x}$-ray untuk melihat sirkulasi limfatik dan kelenjar getah bening untuk tujuan diagnosis memiliki jenis data interger. Dataset Vehicle adalah data mengenai klasifikasi jenis kendaraan berdasarkan sudut pandang gambar yang berbeda memiliki jenis data interger. Dataset Thyroid adalah kanker kelenjar pada leher. Data ini digunakan untuk memprediksi pasien tiroid berdasarkan class eutiroidisme, hipotiroidisme atau hipertiroidisme memiliki jenis data numeric. Dataset Wine adalah hasil analisis kimia dari anggur yang ditanam pada wilayah yang sama di Italia tetapi berasal dari tiga kultivar yang berbeda memiliki jenis data real.

Pemprosesan awal dataset dengan menghapus data outlier dan menggisi data missing value. Penghapusan data outlier dilakukan dengan menghapus data-data yang memiliki simpangan cukup jauh, namun ketika dilakukan pengujian, tidak terjadi perubahan accuracy yang signifikan. Pengisian missing value dilakukan dengan mengisikan nilai rata-rata dari atribut tersebut.

Setelah dilakukan pemprosesan awal, kemudian dilakukan seleksi atribut. Seleksi atribut ini dilakukan menggunakan algoritma particle swarm optimization (PSO). Dataset yang telah diseleksi menggunakan PSO kemudian disiapkan untuk proses validasi data, dengan menggunakan metode 10-fold cross validation dimana dataset hasil seleksi ini dibagi menjadi $90 \%$ data training dan $10 \%$ data testing.

Selanjutnya data training dilakukan pembelajaran untuk memperoleh pola model kemudian pola tersebut dilakukan pengujian menggunakan data testing dengan menggunakan metode cost sensitive decision tree $\mathrm{C} 5.0$ dan cost sensitive naïve bayes. Hasil pengujian kemudian dievaluasi menggunakan parameter accuracy, recall, precision, f-measure dan total cost. Kerangka proses klasifikasi ditampilkan pada Gambar 1.

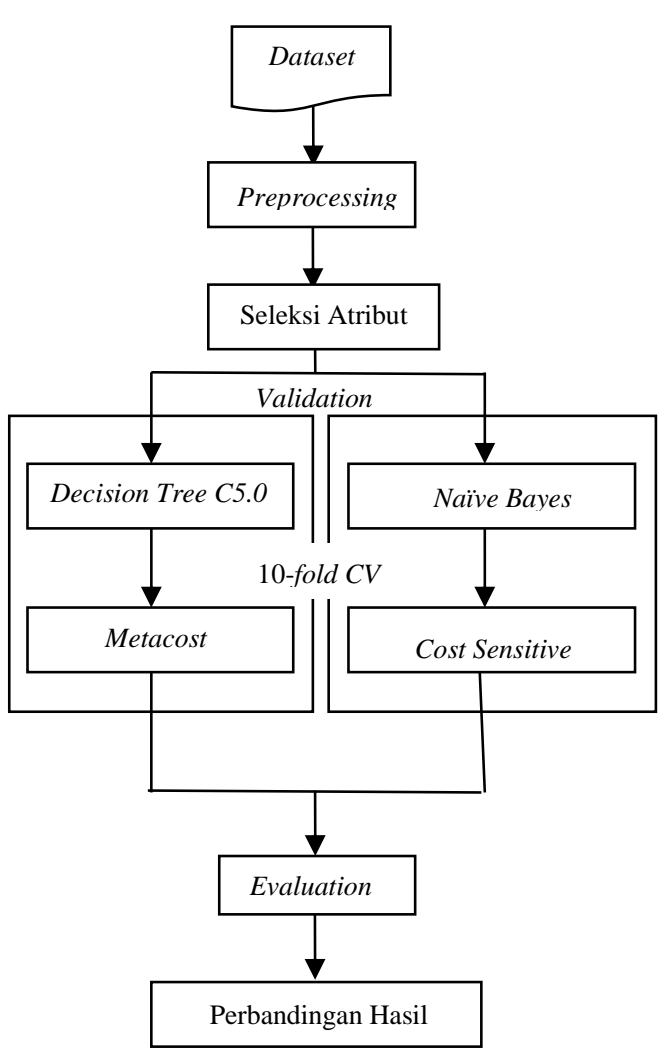

Gambar 1. Flowchart Proses Klasifikasi

A. Konsep particle swarm optimazation

Particle swarm optimization (PSO) merupakan algoritma yang digunakan pada penelitian ini untuk proses seleksi atribut. Konsep dari algoritma PSO adalah memilih atribut yang relevan berdasarkan nilai bobot (w). Tahapan dalam proses particle swarm optimization (PSO) adalah sebagai berikut:

Step 1. Memasukkan dataset.

Step 2. Asumsikan bahwa kecepatan dan posisi awal ditentukan secara random (acak).

Step 3. Hitung kecepatan atribut $i$ pada $d$ dimensi menggunakan persamaan (1).

Step 4. Menghitung posisi atribut $i$ pada $d$ dimensi menggunakan persamaan (2).

Step 5. Melakukan evaluasi Pbest dan Gbest untuk mendapatkan posisi dan kecepatan paling maksimal pada setiap atribut.

Step 6. Evaluasi atribut berdasarkan nilai bobot yang mendekati 0 atau bernilai 0 .

Step 7. Atribut yang tidak relevan dapat dihilangkan.

\section{B. Konsep cost sensitive decision C5.O}

Tahap awal algoritma C5.0 digunakan untuk membuat pola model pohon keputusan berdasarkan nilai entropy dan information gain. Selanjutnya hasil dari pola tersebut dilakukan evaluasi untuk mencari minimum cost dengan menggunakan algoritma 
metacost. Konsep dari metode cost sensitive decision tree C5.0 sebagai berikut:

Step 1. Memasukkan dataset.

Step 2. Menghitung nilai entropy total dataset menggunakan persamaan (3).

Step 3. Menghitung nilai entropy dan gain pada setiap atribut menggunakan persamaan (3) dan (4).

Step 4. Menentukan node akar berdasarkan nilai gain terbesar.

Step 5. Menentukan internal node hingga menghasilkan leaf node berdasarkan nilai entropy dan gain.

Step 6. Proses berhenti jika atribut telah digunakan semua.

Step 7. Menghitung nilai probabilitas setiap leaf node menggunakan persamaan (5). Jika probabilitas > 1 maka akan dilakukan evaluasi menggunakan teknik pruning dan relabel.

Step 8. Mencari pola model decision tree dengan minimum cost menggunakan persamaan (6).

\section{Konsep Cost sensitive Naïve Bayes}

Tahap awal näve bayes menemukan probabilitas prior selanjutnya mencari class probabilitas kondisional sehingga mendapatkan probabilitas posterior kemudian dilakukan evaluasi menggunakan misclassification costs untuk memperoleh minimum cost menggunakan conditional risk. Konsep dari metode cost sensitive naïve bayes sebagai berikut:

Step 1. Memasukkan dataset.

Step 2. Menghitung jumlah class/label.

Step 3. Menghitung jumlah kasus yang sama dengan class yang sama menggunakan persamaan (7).

Step 4. Kalikan semua hasil kriteria pada data.

Step5. Bandingkan hasil class sebagai prediksi class. Step 6. Menghitung conditional risk menggunakan persamaan (8).

Step 7. Mencari pola model naïve bayes dengan minimum cost menggunakan persamaan (9).

\section{Metode Pengujian}

Mengukur performa sistem klasifikasi merupakan hal yang penting dalam data mining. Hasil dari performa sistem klasifikasi membuktikan seberapa akurat sistem tersebut dalam mengklasifikasi data. Confusion matrix merupakan salah satu cara yang digunakan untuk mengukur performa metode klasifikasi. Konsep dari confusion matrix yaitu mengandung sebuah informasi mengenai hasil dari pengklasifikasian. Terdapat empat informasi yaitu true positif (TP), true negative $(\mathrm{TN})$, false positif (FP) dan false negative (FN). Sesuai Ramaswati (2014), Confusion matrix ditunjukkan pada Tabel 2 sebagai berikut:
Tabel 2. Confusion Matrix

\begin{tabular}{lllll}
\hline & \multicolumn{4}{c}{ Predicted Class } \\
\cline { 2 - 5 } Actual & $\mathbf{1}$ & $\mathrm{N}_{(1,1)}$ & $\mathrm{N}_{(1,2)}$ & $\mathrm{N}_{(1,3)}$ \\
Class & $\mathbf{2}$ & $\mathrm{N}_{(2,1)}$ & $\mathrm{N}_{(2,2)}$ & $\mathrm{N}_{(2,3)}$ \\
& $\mathbf{3}$ & $\mathrm{N}_{(3,1)}$ & $\mathrm{N}_{(3,2)}$ & $\mathrm{N}_{(3,3)}$ \\
\hline
\end{tabular}

Cost matrix digunakan untuk mengukur nilai kesalahan pada saat klasifikasi. Cost matrix didefinisikan sebagai $\mathrm{C}(i \mid j)$ dimana $i$ adalah class aktual dan $\mathrm{j}$ adalah class prediksi. Cost kesalahan prediksi pada multiclass ditampilkan sebagai berikut $\left.\mathrm{C}(2,1), \mathrm{C}(3,1), \mathrm{C}(1,2), \mathrm{C}_{(3,2}\right), \mathrm{C}\left({ }_{1,3}\right), \mathrm{C}(2,3)$ ketika cost klasifikasi benar ditampilkan sebagai berikut $\mathrm{C}\left({ }_{1,1}\right)$, $\mathrm{C}(2,2), \mathrm{C}(3,3)$ nilai tersebut dapat dianggap bernilai 0 . Sesuai dengan Xue, et. al. (2013), Table 3 merupakan tampilan dari cost matrix.

Tabel 3. Cost Matrix

\begin{tabular}{lllll}
\hline & \multicolumn{4}{c}{ Predicted Class } \\
\cline { 2 - 5 } Actual Class & $\mathbf{1}$ & $\mathrm{C}_{(1,1)}$ & $\mathrm{C}_{(1,2)}$ & $\mathrm{C}_{(1,3)}$ \\
& $\mathbf{2}$ & $\mathrm{C}_{(2,1)}$ & $\mathrm{C}_{(2,2)}$ & $\mathrm{C}_{(2,3)}$ \\
& $\mathbf{3}$ & $\mathrm{C}_{(3,1)}$ & $\mathrm{C}_{(3,2)}$ & $\mathrm{C}_{(3,3)}$ \\
\hline
\end{tabular}

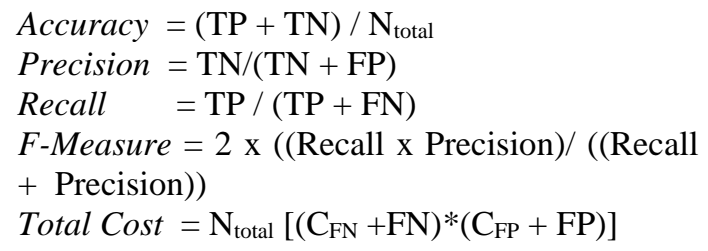

4. Hasil dan Pembahasan

A. Persiapan Data

Pada tahap persiapan data, dilakukan eliminasi data outlier dan pengisian data atribut yang kosong menggunakan data rata-rata atribut dari dataset tersebut. Dari persiapan ini didapati dataset glass sebanyak 214 data dan 9 atribut, lympografi sebanyak 148 data dan 18 atribut, dataset vehicle sebanyak 376 data dan 18 atribut, dataset thyroid 215 data dan 5 atribut, serta dataset wine sebanyak 178 data dan 13 atribut. Hasil pengujian ditampilkan seperti Tabel 4.

Tabel 4. Hasil pengujian PSO

\begin{tabular}{|l|c|c|c|c|}
\hline \multirow{2}{*}{$\begin{array}{l}\text { Dataset } \\
\text { training }\end{array}$} & \multicolumn{2}{|c|}{ Decision Tree } & \multicolumn{2}{c|}{ Nä̈ve Bayes } \\
\cline { 2 - 5 } & DT (\%) & $\begin{array}{c}\text { DT + } \\
\text { PSO } \\
(\%)\end{array}$ & NB (\%) & $\begin{array}{c}\text { NB+ } \\
\text { PSO } \\
(\%)\end{array}$ \\
\hline Glass & 67.29 & 70.09 & 33.18 & 29.44 \\
\hline Lympografi & 75.00 & 78.99 & 74.32 & 80.43 \\
\hline Vehicle & 71.01 & 71.54 & 42.02 & 40.96 \\
\hline Thyroid & 94.42 & 94.42 & 96.74 & 97.67 \\
\hline Wine & 92.86 & 94.38 & 98.31 & 94.94 \\
\hline
\end{tabular}

Berdasarkan hasil pengujian nilai bobot dataset glass, lympografi, vehicle, thyroid dan wine 
menggunakan algoritma PSO pada decision tree dan naïve bayes. Hasil pengujian, diperoleh nilai accuracy maksimal pada decision tree jika nilai atribut berturut-turut $\geq 0.2,>0, \geq 0.3, \geq 0.1,>0$. Sedangkan hasil pengujian seleksi atribut menggunakan algoritma PSO dengan nä̈ve bayes pada dataset lympografi, thyroid dan wine memiliki nilai accuracy maksimal jika atribut berturut-turut $>$ $0,>0.1,>0$ namun pada dataset glass dan vehicle, PSO tidak bisa meningkatkan nilai accuracy.

\section{B. Pengujian dan Analisis}

Penelitian ini dilakukan dengan dua metode pengujian, yaitu menggunakan metode Cost Sensitive Decision Tree C5.0 (csDT) dan metode Cost Sensitive Naive Bayes (csNB).

Percobaan pertama, pengujian pada dataset glass, lympografi, vehicle, thyroid, dan wine menggunakan metode csDT C5.0. Hasil dari pengujian ditampilkan sebagai berikut:

Tabel 5. Hasil Pengujian csDT C5.0

\begin{tabular}{|l|c|c|c|c|}
\hline Dataset & $\begin{array}{c}\text { Accuracy } \\
(\%)\end{array}$ & $\begin{array}{c}\text { Recall } \\
(\boldsymbol{\%})\end{array}$ & $\begin{array}{c}\text { Precision } \\
(\boldsymbol{\%})\end{array}$ & $\begin{array}{c}\text { F- } \\
\text { measure } \\
(\%)\end{array}$ \\
\hline Glass & 76.17 & 76.17 & 95.23 & 84.64 \\
\hline Lympografi & 83.33 & 83.33 & 94.44 & 88.54 \\
\hline Vehicle & 75.27 & 75.27 & 91.76 & 82.70 \\
\hline Thyroid & 95.81 & 95.81 & 97.91 & 96.85 \\
\hline Wine & 95.83 & 95.83 & 94.44 & 96.86 \\
\hline
\end{tabular}

Berdasarkan Tabel 5 menunjukan hasil proses pengujian pada dataset glass, lympografi, vehicle, thyroid, wine memiliki performa accuracy berturutturut, $76.17 \%, 83.33 \%, 75.27 \%, 95.81 \%$, dan 95.83\%. Dimana nilai accuracy menunjukan ratio prediksi benar terbesar didapatkan pada pengujian cSDT C5.0 dengan menggunakan dataset wine. Sedangkan untuk hasil pengujian precision yang menunjukan hasil ratio prediksi terbesar didapatkan dengan menggunakan dataset Thyroid. Hasil lain menunjukan bahwa recall dan $f$-measure memiliki nilai terbesar pada pengujian menggunakan dataset wine masing-masing sebesar $95.83 \%$ dan $96.86 \%$.

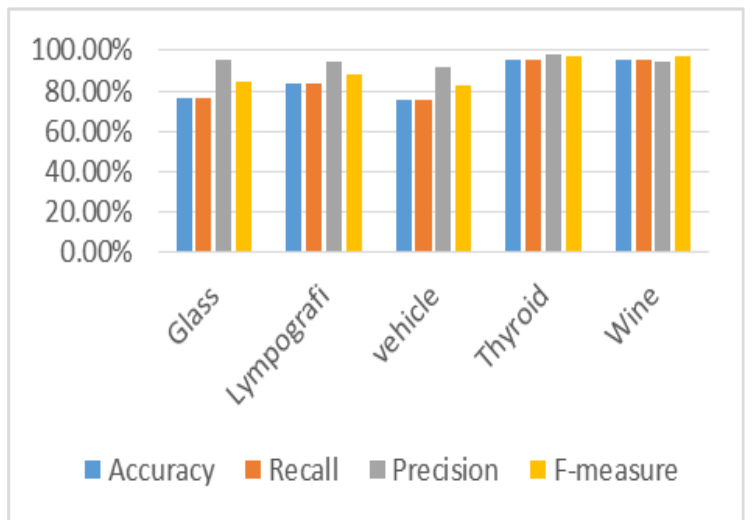

Gambar 2. Diagram Hasil Pengujian csDT

Gambar 2 merupakan visualisasi hasil pengujian Tabel 5 dalam bentuk diagram. Diagram tersebut menunjukan bahwa dengan menggunakan metode csDT C5.0 pada kelima jenis dataset tersebut memiliki prosentase accuracy diatas $75 \%$. Hasil tersebut menunjukan bahwa metode $\operatorname{csDT}$ C5.0 memiliki performa klasifikasi yang cukup baik pada pengujian ini.

Pada percobaan kedua pengujian dilakukan dengan menggunakan metode csNB pada lima dataset. Hasil ditunjukkan pada Tabel 6.

Tabel 6. Hasil Pengujian csNB

\begin{tabular}{|l|c|c|c|c|}
\hline \multicolumn{1}{|c|}{ Dataset } & $\begin{array}{c}\text { Accuracy } \\
(\mathbf{\%})\end{array}$ & $\begin{array}{c}\text { Recall } \\
(\boldsymbol{\%})\end{array}$ & $\begin{array}{c}\text { Precision } \\
(\mathbf{\%})\end{array}$ & $\begin{array}{c}\text { Fmeasure } \\
(\mathbf{\%})\end{array}$ \\
\hline Glass & 32.24 & 32.24 & 86.45 & 46.97 \\
\hline Lympografi & 82.61 & 82.61 & 94.20 & 88.03 \\
\hline Vehicle & 25.53 & 25.53 & 75.18 & 38.12 \\
\hline Thyroid & 97.67 & 97.67 & 98.84 & 98.25 \\
\hline Wine & 94.94 & 94.94 & 97.47 & 96.19 \\
\hline
\end{tabular}

Tabel 6 merupakan hasil pengujian dataset glass, lympografi, vehicle, thyroid dan wine memiliki nilai accuracy berturut-turut sebagai berikut $32.24 \%, 82.61 \%, 25.53 \%, 97.67 \%, 94.94 \%$. Dimana nilai accuracy menunjukan ratio prediksi benar terbesar didapatkan pada pengujian $\operatorname{csNB}$ dengan menggunakan dataset Thyroid. Sedangkan untuk hasil pengujian precision, recall dan $f$ measure menunjukan nilai prosentase terbesar dengan menggunakan dataset Thyroid masingmasing sebesar $94.94 \%, 97.47 \%$ dan $96.19 \%$.

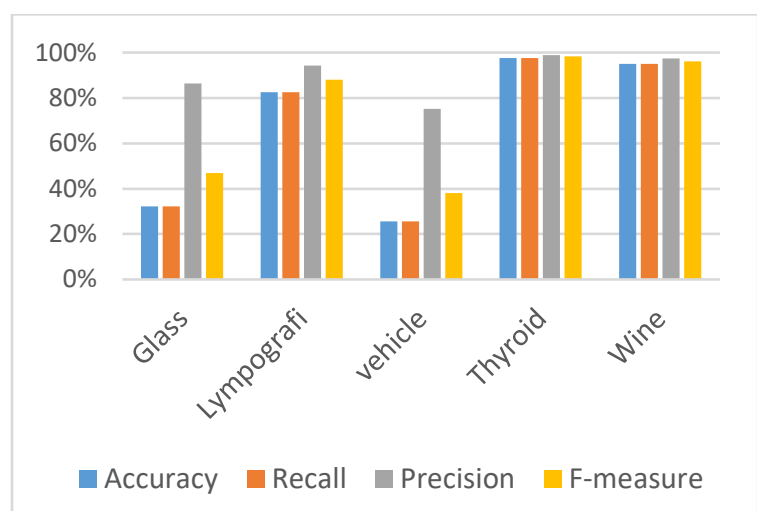

Gambar 3. Diagram Hasil Pengujian csNB

Gambar 3 merupakan visualisasi hasil pengujian Tabel 6 dalam bentuk diagram. Diagram tersebut menunjukan bahwa dengan menggunakan metode $\operatorname{csNB}$ pada kelima jenis dataset tersebut terdapat tiga dataset yang memiliki nilai prosentase diatas $75 \%$ yaitu lympografi, thyroid dan wine. Sedangkan dataset glass dan vehicle memiliki prosentase accuracy dibawah $75 \%$. Hasil tersebut menunjukan bahwa metode $c s N B$ memiliki performa klasifikasi yang kurang baik pada karakteristik dataset jenis glass dan vehicle. 
Tabel 7. Hasil Perhitungan Cost

\begin{tabular}{|c|c|c|c|c|c|c|}
\hline \multirow[b]{2}{*}{ Dataset } & \multicolumn{3}{|c|}{ Decision Tree } & \multicolumn{3}{|c|}{ Nä̈ve Bayes } \\
\hline & $D T$ & $\begin{array}{l}\text { DT + } \\
\text { PSO }\end{array}$ & $c s D T$ & $N B$ & $\begin{array}{l}N B \\
+ \\
P S O\end{array}$ & $c s N B$ \\
\hline Glass & 9800 & 8192 & 5202 & 40898 & 40898 & 42050 \\
\hline Lympografi & 2738 & 1682 & 1058 & 2888 & 1458 & 1152 \\
\hline vehicle & 22898 & 23762 & 17298 & 95048 & 95048 & 156800 \\
\hline Thyroid & 288 & 288 & 162 & 98 & 50 & 50 \\
\hline Wine & 288 & 200 & 98 & 18 & 18 & 162 \\
\hline
\end{tabular}

Tabel 7 merupakan hasil pengujian klasifikasi menggunakan metode decision tree dan nä̈ve bayes, dimana kesalahan klasifikasi dapat dihitung menggunakan cost. Jadi, semakin besar nilai cost maka classifier memiliki performa yang buruk. Hasil pengujian menunjukan bahwa metode cost sensitive mampu meningkatkan performa classifier dengan meminimalkan kesalahan klasifikasi pada metode decision tree dengan baik pada semua dataset yang diuji. Namun, metode cost sensitive tidak mampu meminimalkan kesalahan klasifikasi pada semua data uji jika menggunakan metode nä̈ve bayes. Hal tersebut ditunjukan pada hasil pengujian menggunakan dataset glass dan vehicle yang adanya peningkatan nilai costnya masing-masing sebesar 40898 dan 95048 menjadi 42050 dan 156800 .

Hasil tersebut menunjukan bahwa metode cost sensitive decision tree C5.0 memiliki performa klasifikasi yang baik dan stabil pada kelima data uji. Sedangkan cost sensitive naüve bayes dinilai memiliki performa kurang baik jika melakukan klasifikasi data multiclass.

\section{Kesimpulan}

Berdasarkan hasil pengujian dan evaluasi dapat disimpulkan bahwa pengujian dengan menggunakan metode cost sensitive decision tree C5.0 memiliki nilai accuracy yang lebih baik dari pada menggunakan metode cost sensitive nä̈ve bayes pada dataset glass, lympografi, vehicle dan wine berturut-turut $76.17 \%, 83.33 \%, 75.27 \%$ dan $95.83 \%$. Sedangkan dengan menggunakan metode cost sensitive naïve bayes memiliki nilai accuracy yang lebih baik dari pada cost sensitive decision tree C5.0 pada dataset thyroid sebesar $97.67 \%$. Performa klasifikasi tidak hanya ditentukan pada pemilihan metode namun karakteristik dari data uji meliputi jenis data dan jumlah class juga akan mempengaruhi hasil klasifikasi. Pada penelitian ini menunjukan cost sentive decision tree C5.0 memilki performa yang lebih baik pada jenis data real dan interger sedangkan metode cost naive bayes memiliki performa yang baik jika menggunakan jenis data numerik.

\section{Daftar Pustaka:}

Ali H, M. N. M. Salleh, Saedudin, R. and Hussain, K. (2019): Imbalance class problems in data mining: a review.", Indones. J. Electr. Eng. Comput. Sci., vol. 14, no. 3., 2019, pp. 15601571.

Bernard, S., Chatelain, C., and Adam, S., (2015): The Multiclass ROC Front method for costsensitive classification. Pattern Recognition, vol. 52., 2015: pp. 46-60.

Chai, X., Deng, L., Yang., Q., et al., (2004): Test Cost Sensitive Nä̈ve Bayes Classification., Proceedings of the 4th IEEE International Conference on Data Mining pp.51-58.

Daraei A., (2017): An Efficient Predictive Model for Myocardial Infarction Using Cost-sensitive J48 Model. Iran J Public Health, Vol. 46, No.5. 2017: pp.682-692.

Domingos P., (1999): MetaCost: A general method for making classifiers cost-sensitive. Proceedings of the Fifth International Conference on Knowledge Discovery and Data Mining. ACM Press., 1999, pp. 155164.

Faisal KM, Mofizur RC. (2011): Enhanced classification accuracy on naïve bayes data mining models. International journal of computer applications, 2011, 28(3): 9-16

Friedman N.,Geiger., D and Goldezmidt M., (1997): Bayesian Network Classifier. Machine Learning, 1997, pp:131-163.

Haldankar A.N. (2016): A Cost Sensitive classifier for Big Data. IEEE International Conference on Advances in Electronics, Communication and Computer Technology (ICAECCT).

Jauhari F,, Supianto, A.A., (2019): Building student's performance decision tree classifier using boosting algorithm. Indones. J. Electr. Eng. Comput. Sci., vol. 14, no. 3., 2019, pp. 1298-1304.

Janasthar, S. and A. Hanskunatai, (2014): The ensemble of Nä̈ve Bayes Classifiers for Hotel Searching, International Computer Science and Engineering Conference (ICSEC), 2014.

Larose D. T., (2005): Discovering knowledge in data: an introduction to data mining. Jhon Wiley \& Sons Inc.

Pandya R., dan Pandya, J., (2015): C5.0 Algorithm to Improved Decision Tree with Feature Selection and Reduced Error Pruning. International Journal of Computer Applications, vol. 117., 2015: pp. 0975 8887.

Patel B.R, dan Rana, K.K., (2014): A Survey on Decision Tree Algorithm For Classification. International Journal of Engineering Development and Research, Vol. 2, No. 1., 2014.

Patel B.N, Prajapati, S.G., and Lakhtaria, K.I. (2012): Efficient Classification of Data Using 
Decision Tree. Bonfring international journal of data mining, Vol. 2, No. 1., 2012.

Ramaswati M., (2014): Validating Predictive Performance of Classifier Models for Multiclass Problem in Educational Data Mining, International Journal of Computer Science Issue, Vol. 11, Issue.5., 2014.

Herasmara, R., Muslim, M.A., Mudjirahardjo, P. (2019): Optimasi Struktur Convolutional Neural Network LeNet5m dengan Pendekatan MorphNet, Jurnal EECCIS, Malang, Teknik Elektro Universitas Brawijaya.

Thomas M.C. and Joy A. T. (2006): Elements of imformation Theory, A John Wiley \& Sons, INC., Publication, 2006, pp. 13-14.

Wang, S. and Yao, X., (2012): Multiclass Imbalance Problems : Analysis and Potential Solutions." IEEE Trans. Syst. Man. Cybern., vol. 42, no. 4., 2012, pp. 1119-1130.

Wei S, Ching, Y.K., Chieh, C.S., and Jung, L.Z. (2008): Particle Swarm Optimization for Parameter Determination and Feature Selection of Support Vector Machines. ScienceDirect: Expert System With Aplications., 2008, pp.1817- 1824.

Xiangju L, Hong Z and William Z., (2015): A Cost Sensitive Decision Tree Algorithm with Two Adaptive Mechanisms, Knowledge-Based System, vol. 88, 2015, pp. 24-23.

Xue, B., Zhang, M., \& Browne, W. N. (2013): Particle Swarm Optimization for Feature Selection in Classification: A Multi-Objective Approach. IEEE Transactions on Cybernetics, 43(6), 2013, pp. 1656-1671.

Zhang, S., Zhang, C., and Yang, Q., (2010): Data preparation for data mining. Applied Artificial Intelligence an International Journal, Vol. 17, 2010, pp. 5-6. 